\title{
Oligoclonal T Cell Proliferative Disorder in Combined Immunodeficiency
}

\author{
J. FRENKEL, H. J. NEIJENS, J. C. DEN HOLLANDER, I. L. M. WOLVERS-TETTERO, AND \\ J. J. M. VAN DONGEN \\ Department of Pediatrics [J.F., H.J.N.], Department of Immunology [I.L.M.W-T., J.J.M.v.D.], and Department \\ of Pathology [J.C.d.H.], Academic Hospital Rotterdam/Erasmus University, Rotterdam, The Netherlands
}

\begin{abstract}
Oligoclonal lymphoid proliferations may occur in immunocompromised patients and in the elderly. So far these proliferations have been shown to be of $B$ cell origin. We describe a patient with a combined immunodeficiency, characterized by profound hypogammaglobulinemia and the initial absence of $T$ lymphocytes in the peripheral blood (PB). From the age of $4 \mathrm{yr} \mathrm{CD3}^{+} \mathrm{T}$ cells appeared in $\mathrm{PB}$ in rising numbers. These cells mainly expressed the $\mathrm{CD4}^{-} / \mathrm{CD8}^{+}$phenotype $(\mathrm{CD} 4 / \mathrm{CD} 8$ ratio: $0.1)$. Despite the emergence of $T$ lymphocytes no proliferation of PB mononuclear cells could be induced with phytohemagglutinin, concanavalin $\mathrm{A}$, or pokeweed mitogen. Between the ages of 4 and 6 yr the patient gradually developed hepatosplenomegaly and an interstitial pulmonary infiltrate of unknown origin, necessitating biopsies of both liver and lung. Infiltrates consisting of $\mathrm{CD8}^{+} \mathrm{T}$ lymphocytes were found in the liver as well as the lung. $\mathrm{CD8}^{+}$ $T$ cells were also abundant in the bronchoalveolar lavage fluid. Southern blot analysis of mononuclear cells from PB and of a lung biopsy specimen was performed to investigate if a clonal T cell population was involved. Analysis of the $T$ cell receptor $\beta$ genes revealed that at least three expanded $T$ cell clones were present in $\mathrm{PB}$, one of which had invaded the lung. Thus far, i.e. $2 \mathrm{yr}$ after the initial detection of clonal $T$ cell receptor $\beta$ gene rearrangements, there have been no clinical or histologic signs of malignant behavior. We conclude that this combined immunodeficiency patient has a benign oligoclonal $T$ cell lymphoproliferative disorder. Similar proliferations might well occur in other immunodeficiency states, whether primary or acquired. (Pediatr Res 24: 622-627, 1988)
\end{abstract}

\section{Abbreviations}

BAL, bronchoalveolar lavage

$\mathrm{BM}$, bone marrow

$C$, constant gene segment

Con A, concanavalin A

$D$, diversity gene segment

EBV, Epstein Barr virus

HTLV-1, human T lymphotropic virus type 1

$\mathrm{J}$, joining gene segment

kb, kilobase

McAb, monoclonal antibodies

MNC, mononuclear cells

NHL, non-Hodgkin lymphoma

$\mathrm{PB}$, peripheral blood

PHA, phytohemagglutinin

Received November 26, 1987; accepted July 20, 1988.

Correspondence J. Frenkel, M.D. Department of Immunology, Erasmus University, P.O. Box 1738, 3000 DR Rotterdam, The Netherlands.
PWM, pokeweed mitogen

SCID, severe combined immunodeficiency

CID, combined immunodeficiency

SpA, staphylococcal protein A

TcR, T cell receptor

$V$, variable gene segment

WBC, white blood cell(s)

HIV-I, human immunodeficiency virus type I

In immunodeficient patients the risk of developing cancer, particularly lymphoreticular malignancies, is increased. The majority of the latter consist of B cell NHL (1-3). Benign proliferations of one or more B cell clones may also occur in immunodeficiency, as evidenced by the appearance of transient paraproteins or persistent benign monoclonal gammapathies in serum immunoelectrophoresis $(4,5)$. Furthermore B cell proliferations may occur in organ transplant recipients, of whom some may develop NHL during continued immunosuppressive treatment (6). In such patients immunohistochemical staining of pathology specimens indicated that multiple B cell clones $(7,8)$ were involved.

More recently it has become possible to determine B cell clonality by analysis of Ig gene rearrangements $(9,10)$. As with the Ig genes, the genes that code for the variable parts of TcR chains consist of $V, D$, and $J$ gene segments, which join through rearrangement during $\mathrm{T}$ cell differentiation $(11,12)$. Clonal Ig or TcR gene rearrangements can be detected by Southern blot analysis. Using this technique it has been shown that $T$ cell malignancies, like B cell malignancies, consist of clonal cell populations (12-14).

We present a patient with a CID, who developed an abnormal rise of $\mathrm{CD} 8^{+} \mathrm{T}$ cells in the $\mathrm{PB}$ as well as $\mathrm{CD} 8^{+} \mathrm{T}$ cell infiltrates of lung and liver. Southern blot analysis of DNA from PB MNC and from a lung biopsy specimen revealed the presence of several clonal $\mathrm{T}$ cell populations, though clinically there were no signs of malignant disease.

\section{CASE REPORT}

The patient, a Caucasian boy, born to healthy, nonconsanguinous parents after an uneventful pregnancy and delivery had been well until 5 months old, when his parents noted that he became less active and started to lose weight. At the age of 6 months he was admitted to hospital with Pneumocystis carinil pneumonia. This finding prompted further investigation. Serum Ig was depressed (IgM: $0.29 \mathrm{~g} /$ liter; IgG: $0.68 \mathrm{~g} /$ liter; IgA: $<0.5$ $\mathrm{g} /$ liter), $\mathrm{T}$ cells could not be detected in $\mathrm{PB}$ using the $\mathrm{E}$ rosette test, whereas the percentage of B lymphocytes was normal. The $\mathrm{PB}$ MNC failed to proliferate on stimulation with PHA, Con A, 
or PWM. Erythrocyte levels of adenosine deaminase and purine nucleoside phosphorylase were normal as were neutrophil function assays and determinations of the complement components $\mathrm{C} 3$ and C4. No thymic shadow could be identified on chest $\mathrm{x}-$ rays. There had been no similarly affected children among blood relatives. The pneumonia was successfully treated with trimethoprim. Ig supplementation was achieved with plasma infusions and later with intravenous $\gamma$-globulin. At the age of 7 months he developed extensive candidiasis of the skin and mucous membranes that responded favorably to local antimycotic treatment.

Until the age of 4 he enjoyed fair health and was growing well, despite inadequate $\mathrm{Ig}$ production. From then on he suffered many episodes of maxillary sinusitis, otitis media, and mastoiditis requiring antibiotic treatment and repeated surgical interventions. Bacterial cultures from these sites yielded Haemophilus influenzae twice and Pseudomonas species on several occasions. He developed exertional dyspnea, which steadily worsened over the years, punctuated by acute bronchopulmonary infections caused by the same bacteria, although on one occasion parainfluenza virus type 3 was cultured from the sputum. Repeated chest $\mathrm{x}$-rays showed increasing density of the right middle and lower lobes for which no infectious cause could be identified despite repeated microbiologic investigations of sputum, BAL, and a transbronchial biopsy specimen. A slowly progressive hepatosplenomegaly was also noted from the age of $4 \mathrm{yr}$ on. Examination at the age of 6 revealed a short statured, anemic, dyspneic boy, height $105.5 \mathrm{~cm}$ ( $<3 \mathrm{rd}$ centile for age), weight $17.8 \mathrm{~kg}$ ( \pm 90 th centile for height), respiratory rate at rest $50 / \mathrm{min}$. Over the right lower lung field breath sounds were diminished. The liver extended $5 \mathrm{~cm}$, the spleen $2.5 \mathrm{~cm}$ below the costal margin. The $\mathrm{Hb}$ was $6.4 \mathrm{mmol} /$ liter $(10.3 \mathrm{~g} / \mathrm{dl})$, the WBC $7.4 \times$ $10^{9}$ /liter. Repeated immunologic marker analysis of MNC from $\mathrm{PB}$ revealed persistently low numbers of $\mathrm{CD} 4^{+} \mathrm{T}$ cells, but a gradual rise of $\mathrm{CD} 8^{+} \mathrm{T}$ cells (cf. "Results"). An open lung biopsy and a percutaneous needle biopsy of the liver were performed. The liver specimen showed dense infiltration of portal areas with small lymphocytes and scattered fibroblasts. The lung specimen showed a similar infiltration that diffusely involved the interalveolar septa with focal nodular collections of lymphocytes (Fig.
1). Immunohistochemical staining of both specimens identified the infiltrating lymphocytes as $\mathrm{CD}^{+} \mathrm{T}$ cells, whereas apparently no B cells were present. No $P$. carinii, fungi, or acid fast bacilli could be demonstrated in appropriately stained specimens and no microorganisms could be cultured. No EBV DNA could be detected in the lung specimen by Southern blot analysis (kindly performed by Dr. R. Boom, Department of Virology, University of Amsterdam, Amsterdam, The Netherlands).

His respiratory symptoms improved spontaneously, although chest $\mathrm{x}$-rays showed little change. In the mean time chronic diarrhea developed, caused by Giardia lamblia. Treatment with metronidazole was followed by reduction of diarrhea.

In Figure $2 A$ the WBC count and the course of the patients' illness are summarized from the onset with $P$. carinii pneumonia at the age of 6 months. Figure 2 illustrates the striking absence of symptoms between the ages of 2 and $4 \mathrm{yr}$, followed by frequent sinopulmonary infections.

At present the boy is $8 \mathrm{yr}$ old. His physical condition has remained stable over the recent years despite frequent sinopulmonary infections, compromised growth, and poor exercise tolerance (pulmonary function tests: forced vital capacity $51 \%$ and 1 -s forced expiratory volume $64 \%$ of normal). Psychomotor development has been normal.

In the recent past additional tests have been performed in an attempt to characterize the nature of his immunodeficiency. The data from immunologic marker analysis of the nucleated cells in $\mathrm{PB}, \mathrm{BM}$ and BAL will be described in "Results." Repeated lymphocyte proliferation assays showed no response upon stimulation with Con A, PHA, PWM, or SpA. Also stimulation with anti-CD3 McAb or irradiated allogeneic MNC did not result in obvious proliferation. HLA antigens (HLA-A, -B, and -DR) and the CD11/CD18 antigens (LFA-1, CR3, p150,95) were expressed normally by PB MNC. Results of HLA typing showed the patients PB MNC to be haploidentical with both parents. The HIV-I antigen was not detectable on two occasions. No reverse transcriptase activity was demonstrated on coculture of the patients lymphocytes with human cord blood lymphocytes (kindly performed by Dr. M Tersmette, Central Laboratory of the Blood Transfusion Service, Amsterdam, The Netherlands). Subsequent

Table 1. Results of representative immunologic marker analyses of cell samples and of immunoperoxidase staining of the second open lung biopsy (OLB) specimen

\begin{tabular}{|c|c|c|c|c|c|c|c|c|}
\hline $\begin{array}{c}\text { Source } \\
\text { Age* }\end{array}$ & $\begin{array}{c}\mathrm{PB} \\
5 \mathrm{y} 6 \mathrm{~m} \\
\end{array}$ & $\begin{array}{l}\text { PB } \\
6 y \\
\end{array}$ & $\begin{array}{c}\text { BAL } \\
6 \mathrm{y} 2 \mathrm{~m} \\
\end{array}$ & $\begin{array}{c}\mathrm{PB} \\
6 \mathrm{y} 2 \mathrm{~m} \\
\end{array}$ & $\begin{array}{c}\mathrm{BM} \\
6 \mathrm{y} 2 \mathrm{~m} \\
\end{array}$ & $\begin{array}{r}\text { OLB } \\
6 \mathrm{y} 3 \mathrm{~m} \\
\end{array}$ & $\begin{array}{c}\mathrm{PB} \\
6 \mathrm{y} 10 \mathrm{~m} \\
\end{array}$ & $\begin{array}{c}\mathrm{PB} \\
7 \mathrm{y} 7 \mathrm{~m} \\
\end{array}$ \\
\hline \multicolumn{9}{|l|}{ B cell markers } \\
\hline CDI0 (VIL-A1) & & $1+$ & & 0 & 1 & $-\$$ & & \\
\hline CD19 (B4) & & 17 & 0 & 6 & 8 & - & & \\
\hline $\mathrm{CD} 20(\mathrm{~B} 1)$ & 7 & 9 & 0 & 5 & 8 & - & 8 & 10 \\
\hline \multicolumn{9}{|l|}{$\mathrm{T}$ cell markers } \\
\hline CD3 (Leu-4) & 79 & 60 & 81 & 88 & 34 & ++ & 75 & 83 \\
\hline CD5 (Leu-1) & 80 & & 50 & 70 & 21 & & 55 & \\
\hline CD4 (Leu-3) & 14 & 8 & 5 & 6 & 4 & $+/-$ & 6 & 7 \\
\hline CD8 (Leu-2) & 67 & 60 & 74 & 77 & 29 & ++ & 62 & 75 \\
\hline $\mathrm{CD} 4 / \mathrm{CD} 8$ ratio & 0.2 & 0.1 & 0.1 & 0.1 & 0.1 & low & 0.1 & 0.1 \\
\hline \multicolumn{9}{|l|}{ Myeloid markers } \\
\hline $\mathrm{CD} 13(\mathrm{My} 7)$ & 18 & & 16 & 10 & 6 & - & & \\
\hline CD14 (My4) & 15 & 10 & 10 & 15 & 3 & - & 13 & 7 \\
\hline CD15 (VIM-D5) & 4 & 0 & 0 & 0 & 18 & - & 3 & 0 \\
\hline CD33 (My906) & & & 15 & 9 & 15 & - & & \\
\hline HLA-DR & 91 & 46 & 69 & 74 & & ++ & & 59 \\
\hline
\end{tabular}

* Age of the patient in years $(\mathrm{y})$ and months $(\mathrm{m})$.

$\dagger$ The figures represent percentages of the cells that were expressing the indicated marker.

$\ddagger$ Immunoperoxidase positivity of the infiltrating cells is indicated as follows: ++ (most cells positive) $+/-($ a few cells positive), or - (most cells negative). 
to repeated diphteria/pertussis/poliomyelytis vaccination or the documented parainfluenza infection no specific antibody formation was detected. Although the patient had blood group A, isoagglutinins against blood group B could not be detected.

\section{MATERIALS AND METHODS}

Cell samples. MNC were isolated from $\mathrm{PB}$ and $\mathrm{BM}$ samples by Ficoll-Paque (density $1.077 \mathrm{~g} / \mathrm{cm}^{3}$; Pharmacia, Uppsala, Sweden) density centrifugation. BAL was performed under general anesthesia. The cells in the recovered fluid were used for analysis. All washings were performed in phosphate-buffered saline containing $0.5 \%$ bovine serum albumin, $\mathrm{pH} 7.8$.

Immunologic marker analysis. The $\mathrm{MNC}$ from $\mathrm{BM}$ and $\mathrm{PB}$, as well as the cells from the BAL fluid were analyzed for the expression of the HLA-DR antigen, the $T$ cell markers CD3 (Leu-4), CD4 (Leu-3), CD5 (Leu-1), CD8 (Leu-2) (in initial studies the $T$ cell antigen $C D 2$ was detected by use of the $E$ rosette test), the B cell antigens CD10 (VIL-A1), CD20 (B1), and the myelomonocytic antigens CD14 (My4), CD15 (VIM-D5), and CD33 (My906). The McAb that were used to detect these markers are indicated in parentheses. In addition Leu-7, a McAb that recognizes a membrane antigen on presumed natural killer cells was used. The immunofluorescence stainings and microscopic evaluation were performed as described (15). The frequency of positive cells was calculated as a percentage of the total number of cells evaluated. Absolute numbers of PB cells expressing a particular marker were obtained by a recalculation procedure using the WBC count and leucocyte differential count as parameters.

Southern blot analysis. DNA was prepared from MNC of PB and $\mathrm{BM}$ and from a frozen open lung biopsy specimen as previously described (16). DNA (15 $\mu \mathrm{g})$ was digested with EcoRI (New England Biolabs, Beverly, MA) and the fragments were size separated by electrophoresis in a $0.7 \%$ agarose gel (Sigma Chemical Co., St. Louis, MO). DNA was transferred onto Gene Screen Plus nylon membranes (New England Nuclear, Boston, MA) as previously described (17). TcR- $\beta$ gene rearrangements were detected by hybridization of the filters with a ${ }^{32} \mathrm{P}$-labeled nick-translated $\mathrm{C} \beta$ probe or $\mathrm{J} \beta 2$ probe (18). Hybridization and washing conditions were as described (17).

\section{RESULTS}

The results of representative immunologic marker analyses of MNC from PB and BM and of cells from BAL fluid are shown in Table 1. In addition the semiquantitative results of immunoperoxidase stainings of the lung biopsy specimen are summarized in Table 1. Although immunologic marker analysis initially showed absence of $T$ lymphocytes as determined by the $E$ rosette test, the percentage of $\mathrm{CD}^{+}$cells ( $T$ lymphocytes) at 5 yr of age was $79 \%$ with an abnormally low CD4/CD8 ratio. CD20 $0^{+}$cells (B lymphocytes) were present in normal numbers $\left( \pm 0.41 \times 10^{9}\right.$ / liter), with $98 \%$ of the CD20 $0^{+}$cells expressing both $\mu$ - and $\delta$ heavy chains on the surface membrane and only a few cells expressing $\gamma$ - or $\alpha$-heavy chains, which is normal at this age (19). In $\mathrm{BM}$ samples fewer $\mathrm{CD}^{+}$cells were found. The $\mathrm{CD} 4 / \mathrm{CD} 8$ ratio was again low (Table 1). Cells in the BAL fluid were predominantly $\mathrm{CD}^{+} \mathrm{T}$ lymphocytes as were the cells infiltrating the open lung biopsy specimen (Table 1).

The subsequent rise of $\mathrm{T}$ cells in $\mathrm{PB}$ was completely accounted for by an increase in $\mathrm{CD}^{+}$cells, reaching a maximum of $5.2 \times$

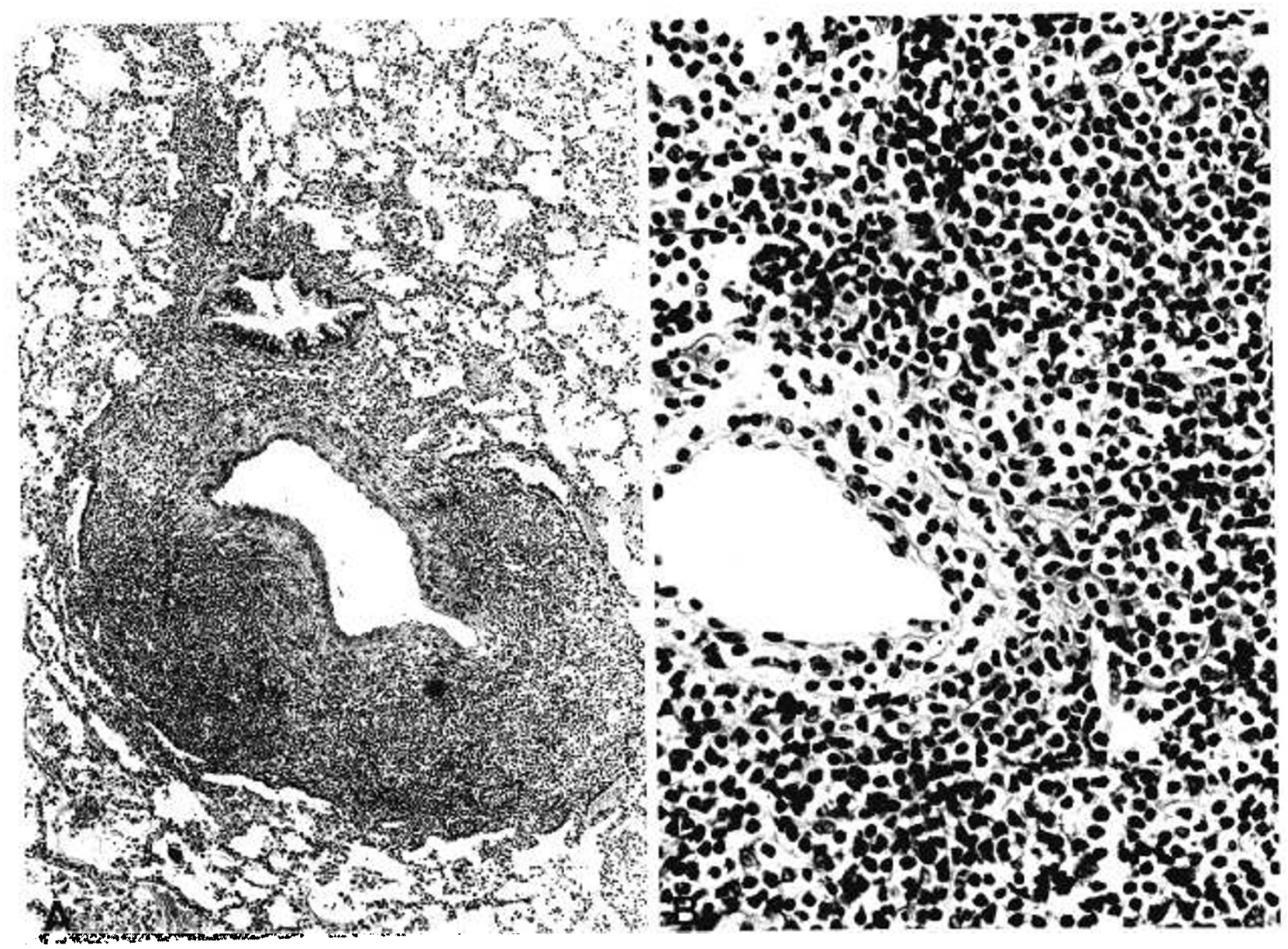

Fig. 1. $A$, the lung biopsy specimen in hematoxylin/azophloxin staining at $60 \times$ magnification. MNC have diffusely infiltrated the interalveolar septa with nodular collections around small airways and blood vessels. $B, 380 \times$ magnification: the infiltrating cells are small lymphocytes and fibroblasts that focally invade the vessel wall. There are no signs of destruction or necrosis. 
$10^{9} /$ liter before declining to the still elevated value of $3.8 \times 10^{9} /$ liter (normal 0.27 to $0.84 \times 10^{9} /$ liter). The number of $\mathrm{CD}^{+}$cells remained abnormally low $\pm 0.4 \times 10^{9} /$ liter (normal 0.54 to 1.68 $\times 10^{9} /$ liter). Four percent of PB MNC were positive for the low affinity Fc-receptor for IgG, CD16 (Leu-11b). No cells in PB or BAL fluid were recognized as natural killer cells by the Leu-7 $(\mathrm{HNK}-1) \mathrm{McAb}$. The rise of $\mathrm{CD} 8^{+}$cells is also demonstrated in Figure $2 B$; in this figure absolute numbers of $\left(\mathrm{CD}^{+}\right)$T lymphocytes, $\mathrm{CD}^{+}$cells, and $\mathrm{CD}^{+}$cells are plotted. Cytogenetical analysis of a bone marrow aspirate (kindly performed by Dr A. Hagemeijer, Department of Cell Biology and Genetics, Erasmus University Rotterdam, Rotterdam, The Netherlands) showed no chromosomal abnormalities.

Southern blot analysis of the TcR- $\beta 1$ gene segments using the $\mathrm{C} \beta 1$ probe revealed only nonrearranged (germline) bands in all $E c o$ RI digests, indicating that the TcR- $\beta 1$ genes of any expanded $T$ cell clone were either deleted or had maintained germline configuration (data not shown). Southern blot analysis of the TcR- $\beta 2$ gene segments using the $\mathrm{J} \beta 2$ probe (Fig. 3 ) revealed that in addition to the $4.1 \mathrm{~kb}$ germline band four strong nongermline bands $(7.8,6.6,6.0$, and $5.0 \mathrm{~kb})$ were present in the case of $P B$. On longer exposure two weak additional bands were observed. Identical results could be obtained with three other PB samples. Analysis of the lung specimen revealed two rearranged bands, corresponding to the 7.8 and $6.0 \mathrm{~kb}$ bands in PB (Fig. 3). In the case of BM four very weak bands were detected, which corresponded to the four strong bands in PB (data not shown). The observed germline bands were most probably derived from non$T$ cells such as B lymphocytes and myeloid cells or lung macrophages and pneumocytes. These data indicate that in the PB samples at least three clonal $\mathrm{T}$ cell populations were present, assuming that each clone had rearranged both $\mathrm{TcR}-\beta 2$ gene alleles. Two of these clones were also found in BM, one of which was also probably present in the lung.

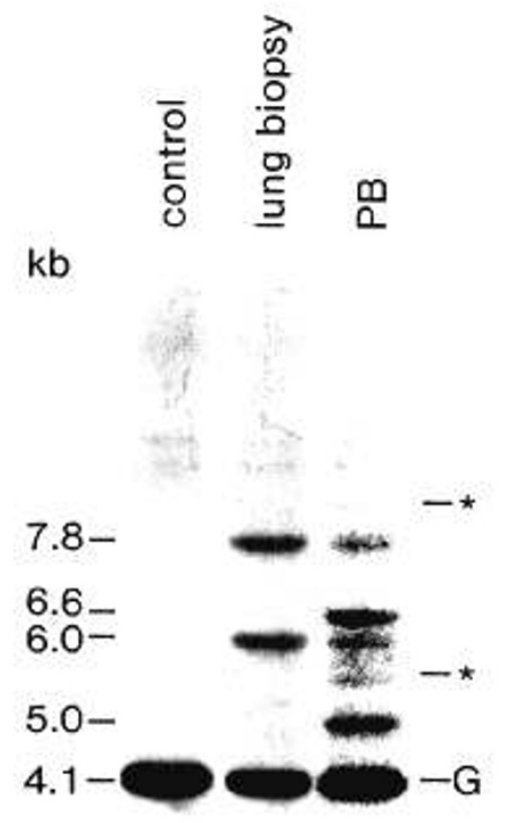

Fig. 3. Southern blot of size separated EcoRI DNA digests, hybridized with the J $\beta 2$-probe. The control DNA is derived from a B cell leukemia with germline TCR- $\beta$ genes. The estimated mol. wt. of the strong rearranged bands and the germline band $(G)$ are indicated. The weak bands in the PB lane are indicated with an asterisk.

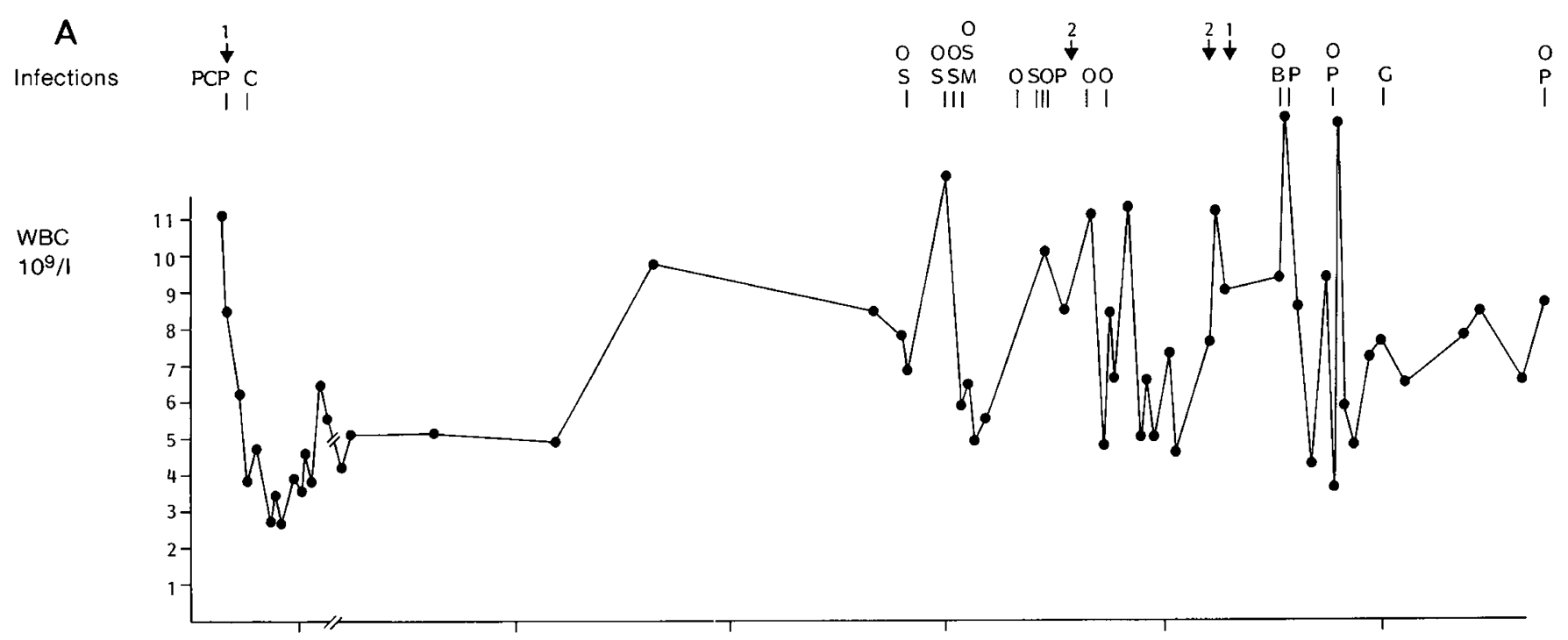

B

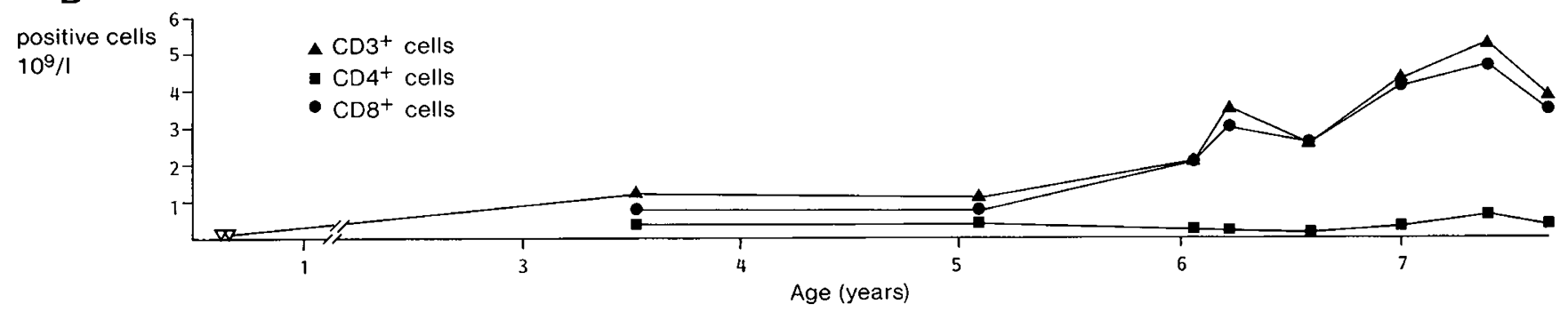

Fig. 2. $A$, WBC counts, infectious episodes ( $P C P, P$. carinii pneumonia; $C$, candidiasis; $S$, sinusitis; $O$, otitis; $M$, mastoiditis; $B$, bronchitis; $P$, pneumonia; and $G$, Giardiasis) and diagnostic procedures ( 1 , open lung biopsy, $2, \mathrm{BAL}) . B$, absolute numbers of $\mathrm{T}$ cells and $\mathrm{T}$ cell subsets. Figures were calculated as WBC count $\left(\times 10^{-4}\right) \times(\%$ lymphocytes $+\%$ monocytes $) \times \% \mathrm{CD}^{+}$cells $(\boldsymbol{\Lambda})$, E-rosette ${ }^{+}$cells $(\nabla), \mathrm{CD}^{+}$cells $(\square)$ and $\mathrm{CD} 8^{+}$cells (O). 


\section{DISCUSSION}

The immunodeficient patient presented here is at present $8 \mathrm{yr}$ old which is in contrast with the usual course of SCID (20). The severe recurrent infections at multiple sites caused by a variety of pathogens including opportunists combined with the onset at the age of 5 months are typical of a profound primary immunodeficiency. The severe Ig deficiency, the inability to mount a humoral response on antigenic challenge, and the lack of in vitro response to PWM and $\mathrm{SpA}$ are compatible with a $\mathrm{B}$ cell disorder, whereas the initial absence of $\mathrm{T}$ lymphocytes, the lack of in vitro response to $\mathrm{T}$ cell mitogens and allogeneic irradiated $\mathrm{MNC}$ indicate a disturbance of the $T$ cell system. The CID in this patient should be considered a primary immunodeficiency despite the absence of consanguinity or similarily affected cases among blood relatives, because no known immunosuppressive cause could be identified. Although the initial presentation of this case is compatible with SCID (21), the subsequent course is not.

Immunodeficiencies predispose to lymphoproliferative diseases. In general these proliferations are of $\mathrm{B}$ cell origin, but $\mathrm{T}$ cell lymphoproliferative disorders are common in ataxia telangiectasia. Therefore the development of oligoclonal $\mathrm{T}$ cell proliferations in our patient is suggestive of ataxia telangiectasia. However, the profound CID of early onset and the lack of neurologic signs and telangiectasia argue strongly against this diagnosis. In addition, T cell proliferations in ataxia telangiectasia generally show chromosomal abnormalities (21), which were not detected in this patient.

The T cells that appeared in this patient's PB from the age of 4 were $\mathrm{CD} 8^{+}$, just like the lymphocytic infiltrates that developed in liver and lung. The clinical and pathologic findings in this case are reminiscent of those with lymphocytic interstitial pneumonia, a disease that is common among children who are immunodeficient due to infection with HIV. Lymphocytic interstitial pneumonia is characterized by diffuse infiltration of alveolar septa with lymphocytes (but in contrast to this case also with plasma cells), often forming primitive follicles (22). The predominant lymphocytes in those infiltrates have been reported to be $\mathrm{CD}^{+} / \mathrm{CD}^{-} \mathrm{T}$ cells $(23,24)$ by some authors, but other authors have reported the presence of mainly B lymphocytes (25). Pulmonary lymphoma could not be excluded on histologic grounds, but it is improbable in view of the clinical course.

Southern blot analysis indicated that in the PB samples at least three clonal $T$ cell populations were present. In the pulmonary infiltrate a single $\mathrm{T}$ cell clone predominated, probably identical to one of the three $\mathrm{T}$ cell clones in PB. Clonality is not synonymous with malignancy and other patients with benign clonal $\mathrm{T}$ cell disorders (26) have been described. However, the finding by Southern blot analysis of multiple $\mathrm{T}$ cell clones in a single specimen is unusual $(21,27,28)$.

Transient monoclonal and oligoclonal paraproteins have been observed in primary immunodeficiencies and in secondary immunodeficiency states after allogeneic bone marrow transplantation and during pharmacologic immunosuppression $(4,5)$. In patients receiving immunosuppressive agents polyclonal $\mathrm{B}$ cell proliferations occur that may resolve once immunosuppression is discontinued (6). These lymphoproliferative states appear to be caused by EBV. In addition multiple $B$ cell clones have been demonstrated in both immunocompetent (28) and immunosuppressed $(7,8)$ lymphoma patients. Although the mechanisms by which immunodeficiency predisposes to B cell lymphoproliferative disorders are not well understood, it is conceivable that failing $T$ cell control allows inappropriate expansion of a few clones (29). Animal studies support this model (30). Although these clonal B cell proliferations may occasionally progress to malignant lymphoma, more seem to be transient or at least initially benign and reversible (31). In other instances failing $\mathrm{T}$ cell defence against EBV may allow virally infected cells to proliferate unchecked.

The emergence in our CID patient of clonal $\mathrm{T}$ cell populations might similarly be explained by failing immunoregulatory mechanisms. It is of interest in this respect that we also detected a clonal $\mathrm{CD}^{+} \mathrm{T}$ cell population in the $\mathrm{PB}$ of a kidney transplant recipient during immunosuppression (van Dongen JJM, unpublished data). In neither case could it be ascertained which, if any, antigen triggered these proliferations in the first place. If virally induced proliferation were to account for the oligoclonal $\mathrm{T}$ cell expansion, it remains unclear which virus might be responsible. EBV is only known to infect B cells and $\mathrm{CD}^{+}$cells (31) and no EBV DNA could be detected in the pulmonary infiltrate. Even though HTLV-I may infect $\mathrm{CD} 8^{+}$cells $(32)$, we have no data in support of HTLV-I infection. Yet another remote possibility, namely that the $T$ cell clones were of maternal or blood transfusion donor origin, is rendered unlikely by the finding that the patient was HLA haploidentical with both parents at a time when the majority of $\mathrm{PB}$ MNC consisted of the $\mathrm{CD} 8^{+} \mathrm{T}$ cells. Thus far the clonal $\mathrm{CD} 8^{+}$populations in this CID patient and the above mentioned kidney transplant recipient have been present for 2 and $3 \mathrm{yr}$, respectively, without any sign of malignancy.

We conclude that a benign oligoclonal $\mathrm{CD} 8^{+} \mathrm{T}$ cell proliferative disorder emerged in a CID patient giving rise to a lymphocytic interstitial lung infiltrate. Similar proliferations may also occur in other primary or acquired immunodeficiency states.

Acknowledgments. The authors gratefully acknowledge Prof. Dr. R. Benner for his continuous support and advice, C. J. van Dijk and T. M. van Os for their expert photographical assistance, and J. de Goey-van Dooren and G. de Korte for their skillful secretarial support.

\section{REFERENCES}

1. Penn I 1981 Depressed immunity and the development of cancer. Clin Exp Immunol 46:459-474

2. Kaplan MH, Susin M, Pahwa SG, Fetten J, Allen SL, Lichtman S, Sarngadharan MG, Gallo RC 1987 Neoplastic complications of HTLV-III infection. Am J Med 82:389-396

3. Filipovich AH, Zerbe D, Spector BD, Kersey JH 1984 Lymphomas in patients with naturally occurring immunodeficiency disorders. In: Margrath IT O'Connor GT, Ramot B (eds) Pathogenesis of Leukemias and Lymphomas, Environmental Influences. Raven Press, New York, pp 225-234

4. Vossen JM, 1985 Monoclonal gammapathies in immunodeficiencies. In: Radl J, Hijmans W, Van Camp B (ecis) Monoclonal gammapathies-Clinical Significance and Basic Mechanisms. Eurage, Rijswijk, The Netherlands, pp $41-48$

5. Radl J, Valentijn RM, Haaijman JJ, Paul LC 1985 Monoclonal gammapathies in patients undergoing immunosuppressive treatment after renal transplantation. Clin Immun Immunopathol 37:98-102

6. Starzl TE, Nalesnik MA, Porter KA, Ho M, Iwatsuki S, Griffith BP, Rosentha JT, Hakala TR, Shaw Jr BW, Hardesty RL, Atchison RW, Jaffe R, Bahnson HT 1984 Reversibility of lymphomas and lymphoproliferative lesions developing under cyclosporin-steroid therapy. Lancet 1:583-587

7. Frizzera G, Hanto DW, Gajl-Peczalska KJ, Rosai J, McKenna RW, Sibley RK, Holahan KP, Lindquist LL 1981 Polymorphic diffuse B-cell hyperplasias and lymphomas in renal transplant recipients. Cancer Res 41:42624279

8. Cleary ML, Sklar J 1984 Lymphoproliferative disorders in cardiac transplant recipients are multiclonal lymphomas. Lancet 2:489-493

9. Cleary ML, Trela MJ, Weiss LM, Warnke R, Sklar J 1985 Most null large cell lymphomas are B lineage neoplasms. Lab Invest 53:521-525

10. Cleary ML, Chao J, Warnke R, Sklar J 1984 Immunoglobulin gene rearrangement as a diagnostic criterion of B-cell lymphoma. Proc Natl Acad Sci USA 88:593-597

11. Kronenberg M, Siu G, Hood LE, Shastri N 1986 The molecular genetics of the T-cell antigen receptor and T-cell antigen recognition. Annu Rev Immunol 4:529-591

12. Van Dongen JJM, Quertermous $\Upsilon$, Bartram CR, Gold DP, Wolvers-Tettero ILM, Comans-Bitter WM, Hooijkaas H, Adriaansen HJ, de Klein A, Raghavachar A, Ganser A, Duby AD, Seidman JG, van den Elsen P, Terhorst $\mathrm{C} 1987 \mathrm{~T}$ cell receptor-CD3 complex during early $\Upsilon$ cell differentiation. Analysis of immature $T$ cell acute lymphoblastic leukemias (T-ALL) at DNA RNA and cell membrane level. J Immunol 138:1260-1269

13. O'Connor NTJ, Weatherall DJ, Feller AC, Jones D, Pallesen G, Stein H, Wainscoat JS, Gatter KC, Isaacson P, Lennert K, Ramsey A, Wright DH, Mason DY 1985 Rearrangement of the T-cell-receptor $\beta$-chain gene in the diagnosis of lymphoproliferative disorders. Lancet 1:1295-1297

14. Aisenberg AC, Krontiris TG, Mak TW, Wilkes BM 1985 Rearrangement of the gene for the beta chain of the T-cell receptor in T-cell chronic lymphocytic leukemia and related disorders. N Engl J Med 313:529-533 
15. Van Dongen JJM, Adriaansen HJ, Hooijkaas H 1987 Immunological marker analysis of cells in the various hematopoietic differentiation stages and their malignant counterparts. In: Ruiter DJ, Fleuren GJ, Warnaar SO (eds) Application of Monoclonal Antibodies in Tumor Pathology. M Nijhoff Publishers, Dordrecht, pp 87-116

16. Jeffreys AJ, Flavell RA 1977 A physical map of the DNA regions flanking the rabbit $\beta$-globin gene. Cell 12:429-439

17. Maniatis T, Fritsch EF, Sambrook J 1982 Molecular cloning: A Laboratory Manual Cold Spring Harbor Laboratory, Cold Spring Harbor, New York

18. Duby AD, Seidman JG 1986 Abnormal recombination products result from aberrant DNA rearrangement of the human T-cell antigen receptor $\beta$-chain gene. Proc Natl Acad Sci USA 83:4890-4894

19. Durandy A 1986 Methoden zur untersuchung der spezifischer immundefektsyndrome. In: Hitzig WH, Griscelli C (eds) Pädiatrische Immunologie. Georg Thieme Verlag, New York, pp 44-54

20. Rosen FS, Cooper MD, Wedgwood RJP 1984 The primary immunodeficiencies. N Engl J Med 311:300-310

21. Hollis J, Kennaugh AA, Butterworth SV, Taylor AMR 1987 Growth of large chromosomally abnormal $\mathrm{T}$ cell clones in ataxia telangiectasia patients is associated with translocation at $14 \mathrm{q} 11$. Hum Genet 76:389-395

22. Liebow AA, Carrington CB 1973 Diffuse pulmonary lymphoreticular infiltrations associated with dysproteinemia. Med Clin North Am 57:809-843

23. Pahwa S, Fikrig S, Kaplan M, Kahn E, Pahwa R 1986 Expressions of HTLVIII infection in a pediatric population. Adv Exp Med Biol 187:45-51

24. Kornstein MJ, Pietra GG, Hoxie JA, Conley ME 1986 The pathology and treatment of interstitial pneumonitis in two infants with AIDS. Am Rev Respir Dis 133:1196-1198
25. Andiman WA, Martin K, Rubinstein A, Pahwa S, Eastman R, Katz BZ, Pitt J, Miller G 1985 Opportunistic lymphoproliferations associated with EpsteinBarr viral DNA in infants and children with AIDS. Lancet 2:1390-1393

26. Weiss LM, Wood GS, Trela M, Warnke RA, Sklar J 1986 Clonal T-cell populations in lymphomatoid papulosis. N Engl J Med 31 5:475-479

27. Berliner N, Duby AD, Linch DC, Murre C, Quertermous T, Knott LJ, Azin T, Newland AC, Lewis DL, Galvin MC, Seidman JG 1986 T cell receptor gene rearrangements define a monoclonal $\mathrm{T}$ cell proiiferation in patients with $\mathrm{T}$ cell lymphocytosis and cytopenia. Blood 67:914-918

28. Sklar J, Cleary ML, Thielemans K, Gralow J, Warnke P, Levy R 1984 Biclonal B-cell lymphoma. N Engl J Med 311:20-27

29. Radl J 1985 Four major categories of monoclonal gammapathies introductory remarks. In: Radl J, Hijmans W, van Camp B (eds) Monoclonal Gammapathies-Clinical Significance and Basic Mechanisms. Eurage, Rijswijk, The Netherlands, pp 3-8

30. Benner R, Van Den Akker Th W, Radl J 1985 Monoclonal gammapathies in immunodeficient animals-a review. In: Radl J, Hijmans W, van Camp B (eds) Monoclonal gammapathies-Clinical Significance and Basic Mechanisms. Eurage, Rijswijk, The Netherlands, pp 97-102

31. Jones JF, Shuin S, Abramowsky C, Tubbs RR, Sciotto CG, Wahl R, Sands J, Gottman D, Katz BZ, Sklar J 1988 T-cell lymphomas containing EpsteinBarr viral DNA in patients with chronic Epstein-Barr virus infections. N Engl J Med 318:733-741

32. Harper ME, Kaplan MH, Marsele LM, Pahwa SG, Chayt KJ, Sarngadharan MG, Wong-Staal F, Gallo R 1986 Concomitant infection with HTLV-I and HTLV-III in a patient with T8 lymphoproliferative disease. N Engl $\mathrm{J}$ Med 315:1073-1078 